\title{
IMPLEMENTASI METODE AGENT BASED MODELING UNTUK EVAKUASI BENCANA TSUNAMI PADA GEDUNG J UNIVERSITAS BENGKULU, INDONESIA
}

\author{
Deni Putrah Pratama ${ }^{1}$, Hardiansyah ${ }^{2}$, Yuzuar Afrizal ${ }^{3}$, Lindung Zalbuin Mase ${ }^{4}$ \\ 1234 Program Studi Teknik Sipil - Fakultas Teknik, Universitas Bengkulu \\ Jl. WR. Supratman, Kandang Limun, Muara BangkaHulu, Kota Bengkulu, (0736) 38119 \\ *Corresponding Author's E-mail: lmase@unib.ac.id
}

\begin{abstract}
ABSTRAK
Gedung J Universitas Bengkulu merupakan gedung kuliah yang digunakan oleh Fakultas Hukum. Gedung J sangat dekat dengan pesisir pantai menyebabkan gedung ini sangat rawan terhadap bencana tsunami. Jalur evakuasi bencana sangat dibutuhkan untuk menanggulangi dan mengurangi korban jiwa. Penelitian ini bertujuan untuk merencanakan model perjalanan evakuasi bencana tsunami dan mengatasi ruas jalan yang bermasalah. Penelitian ini menggunakan metode pemodelan Agent Based Modelling dengan bantuan aplikasi NetLogo versi 6.0.4. Data primer yang digunakan adalah denah gedung dan geometri jaringan jalan. Data sekunder yang diperlukan meliputi jumlah orang yang ada di dalam gedung kuliah. Pengambilan kuesioner dilaksanakan dengan pengambilan sampel, kemudian data dianalisis secara statistik meliputi uji validitas data, derajat kejenuhan, volume, kapasitas, dan tes analisis regresi linier sederhana. Penelitian ini menggambarkan 12 ruas jalan dan 3 rute alternatif. Analisis data yang dilakukan menunjukkan kondisi ruas jalan yang ditinjau berdasarkan hasil perbandingan data kuesioner dan simulasi. Berdasarkan perhitungan dan kondisi responden diperoleh bahwa jalur alternatif 1 lebih banyak di pilih, dikarenakan jarak tempuh yang pendek dan dekat dengan pintu keluar. Ada beberapa faktor yang menjadi hambatan proses evakuasi yaitu, jarak tempuh, dan kapasitas jalan tidak memadai. Diperlukan solusi terhadap permasalahan yang ada dengan cara mengubah dimensi dan pelebaran jalan.
\end{abstract}

Kata Kunci: Permodelan, Evakuasi, Gedung J, NetLogo

\begin{abstract}
Gedung J University of Bengkulu is a lecture building used by the Faculty of Law. Gedung J is very close to the shoreline. It indicates that this building is very vulnerable to tsunami. Disaster evacuation routes are therefore needed. This study aims to plan tsunami disaster evacuation routes models and overcome problematic roads. This study employs Agent Based Modeling method under the framework of NetLogo application version 6.0.4. The primary data used is the building plan and road network geometry. Secondary data needed included the data of people population in the building. Questionnaires were taken by sampling, then data were analyzed statistically on the basis of test data validity, degree of saturation, volume, capacity, and simple linear regression analysis tests. This study described 12 road segments and 3 alternative routes. Data analysis performed shows the condition of the road that was reviewed based on the results of comparison of questionnaire and simulation data. Based on the calculations and respondents, it was found that the alternative Route 1 was preferred, since the access to the exit is short-travel. There are several factors that hinder the evacuation process, i.e. mileage and road capacity. Solutions by road changing dimensions and road broadening are needed to overcome this problem
\end{abstract}

Key Word: Modelling, Evacuations, Building J, NetLogo.

\section{PENDAhuluan}

Bengkulu merupakan salah satu provinsi di Indonesia yang di bagian barat berbatasan dengan Samudra Hindia, dimana terdapat Subduksi Sumatera Lempeng Indo-Australia dan Eurasia. Pergerakan lempeng yang secara tiba-tiba inilah yang mengakibatkan terjadinya potensi gempa bumi dan tsunami. Kerentanan alam ini hampir sepanjang pesisir Kota Bengkulu rawan.

Natawidjaja [1] menyatakan bahwa Kota Bengkulu telah dua kali diterjang oleh gelombang tsunami yang disebabkan akibat pergerakan antara kedua lempeng, yaitu Lempeng Indo-Australia dan Lempeng Eurasia secara mendadak. Kedua kejadian tersebut terjadi pada tahun 1797 dan tahun 1833. Saat ini Kota Bengkulu sering mengalami gempa di antaranya berupa gempa kecil. Meskipun demikian jika terjadi cukup besar akan sangat berpotensi membangkitkan gelombang tsunami. 
Gedung J Universitas Bengkulu (UNIB) merupakan Gedung Kuliah Bersama Fakultas Hukum yang memiliki jarak 987 m dari tepi pantai. Gedung $\mathrm{J}$ tersebut memiliki daya tampung kurang lebih 370 mahasiswa. Peringatan dan rambu-rambu jalur evakuasi bencana pada gedung ini masih sangat kurang. Potensi terjadinya tsunami sangatlah besar pada gedung $\mathrm{J}$ ini.

Dengan sering terjadinya gempa serta kondisi jaringan jalan khususnya di Universitas Bengkulu, penelitian ini menunjukkan evakuasi individu-individu pada Gedung J terhadap jaringan jalan Universitas Bengkulu. Serta mengetahui jalur evakuasi yang tepat dengan metode Agent Based Modelling (ABM).

\section{TINJAUAN PUSTAKA}

\subsection{Pengertian Bencana}

Departemen Kesehatan [2] menyatakan bahwa suatu peristiwa yang terjadi pada suatu daerah yang mengakibatkan kerusakan ekologi, kerugian, hilangnya nyawa manusia, serta memburuknya kesehatan dan pelayanan kesehatan yang bermakna sehingga memerlukan bantuan dari pihak luar. Berikut ini faktor penyebab terjadinya bencana, yaitu: (a) faktor alam (natural disaster) karena fenomena alam tanpa campur tangan manusia. (b) faktor non alam (non-natural disaster) yaitu bukan karena fenomena alam dan bukan juga ulah manusia. (c) faktor manusia (man made disaster) yaitu murni akibat perbuatan manusia.

\subsection{Evakuasi Bencana}

Evakuasi merupakan kemampuan manusia dalam mengambil tindakan dengan cepat, tanggap, tepat, dan terarah berdasarkan prosedur melakukan penyelamatan diri dari bencana. Jalur alternatif ketika evakuasi adalah kita dianjurkan untuk memilih jalur yang aman dan tercepat menuju lokasi pengungsian Manini [3].

Jalur evakuasi merupakan jalur yang dilewati pengungsi dengan pergerakan yang cepat dan tepat untuk menjauh dari lokasi ancaman menuju ke tempat yang lebih aman [4]. Berikut ini merupakan klasifikasi fungsi jalan untuk melakukan evakuasi bencana :

a. Jalan arteri yaitu jalan yang melayani angkutan utama.

b. Jalan kolektor yaitu jalan yang melayani angkutan pengumpul/pembagi.

c. Jalan lokal yaitu jalan yang melayani angkutan setempat.

\subsection{Analisis Model Transportasi}

Hardiansyah [5] berpendapat bahwa pemodelan evakuasi merupakan cakupan wilayah studi yang sangat luas, sehingga menjadi kategori konsep makroskopis. Pemodelan makroskopis dapat dipakai untuk mengevaluasi kinerja jaringan jalan selama kondisi darurat bencana dengan skala studi luas.

Pemodelan transportasi berbasis agent memiliki kelebihan, yaitu pengungsi dapat menambah wawasan akan proses evakuasi, konsep ini hanya mencakup wilayah kajian yang terbatas. Kemudian konsep pemodelan transportasi memiliki kelebihan dapat menangkap pola pergerakan kendaraan lalu lintas dalam skala yang besar. Hasil utama dari analisis percobaan berupa waktu evakuasi dan rute evakuasi yang padat, yang harus di tekankan pada analisis tersebut model evakuasi memerlukan ketepatan pengumpulan data, proses analisa dan kalibrasi Santosa [6]

\subsection{Agent Based Modelling (ABM)}

Bata [7] Menyatakan Agent Based Modelling percobaan dengan menggunakan konsep agent dan interaksi dalam mendapatkan fenomena dan perilaku baru. Agent Based Modelling dapat dikatakan suatu paradigma dalam membangun percobaan. Keuntungan dari menggunakan Agent Based Modelling adalah kita dapat menganalisis perilaku pergerakan agen dan mempelajari dinamika sistem pada saat evakuasi. Analisis tersebut juga dapat menjawab pertanyaan "bagaimana-jika" mengenai berbagai strategi pengendalian model evakuasi.

\subsection{Kinerja Jaringan Jalan}

Kinerja jaringan jalan terdiri dari volume kendaraan, kapasitas jalan, dan derajat kejenuhan. PKJI [8] menyatakan kapasitas diimplementasikan sebagai arus lalu lintas puncak dalam satuan kendaraan ringan per jam (skr/jam) yang perlu diperhatikan untuk kinerja jalan adalah lingkup geometri, lingkungan, dan lalu lintas. Derajat kejenuhan merupakan tolak ukur utama yang digunakan untuk menentukan tingkat kinerja jaringan jalan. 
Tabel 1. Parameter Kinerja jaringan jalan

\begin{tabular}{|c|c|}
\hline Kapasitas Jalan & $\mathrm{C}=C_{0} x F C_{L J} x F C_{P A} x F C_{H S} x F C_{U K}$ \\
\hline Derajat Kejenuhan & $D J=\frac{Q}{C}$ \\
\hline
\end{tabular}

Keterangan:

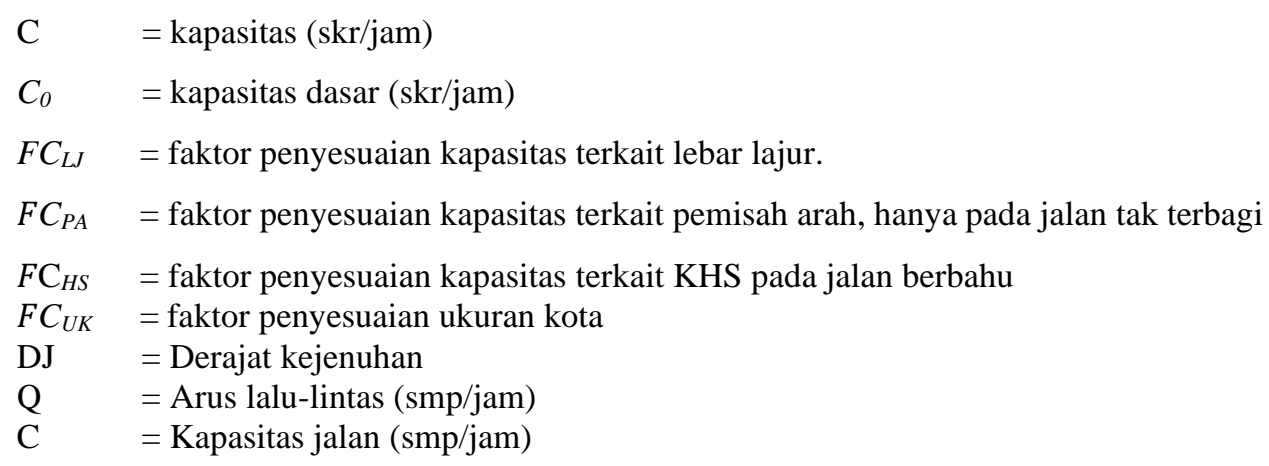

\subsection{Distribusi Regresi Linear Sederhana}

Suatu metode persamaan regresi linear yang melibatkan suatu model persamaan yang menggambarkan hubungan antara variabel X dan Y, yang biasanya digambarkan dalam bentuk garis lurus. Tujuan akhir dari regresi linear untuk mencari nilai $\mathrm{r} 2$ sebagai hasil akhir analisis.

\begin{tabular}{c|l}
\hline \multicolumn{2}{c}{ Tabel 2. Parameter regresi linear } \\
\hline Konstanta, berpotong sumbu Y & $a=\frac{\left(\sum Y_{i}\right)\left(\sum X_{i}^{2}\right)-\left(\sum X_{i}\right)\left(\sum X_{i} Y_{i}\right)}{n \sum X_{i}^{2}-\left(\sum X_{i}\right)^{2}}$ \\
\hline Konstanta regresi & $b=\frac{n \sum X_{i} Y_{i}-\left(\sum X_{i}\right)\left(\sum Y_{i}\right)}{n \sum X_{i}^{2}-\left(\sum X_{i}\right)^{2}}$ \\
\hline Nilai regresi linear & $r=\frac{n \sum X_{i} Y_{i}-\left(\sum X_{i}\right)\left(\sum Y_{i}\right)}{\sqrt{\left\{n \sum X_{i}^{2}-\left(\sum X_{i}\right)^{2}\right\}\left\{\mathrm{n} \sum Y_{i}^{2}-\left(\sum Y_{i}\right)^{2}\right\}}}$
\end{tabular}

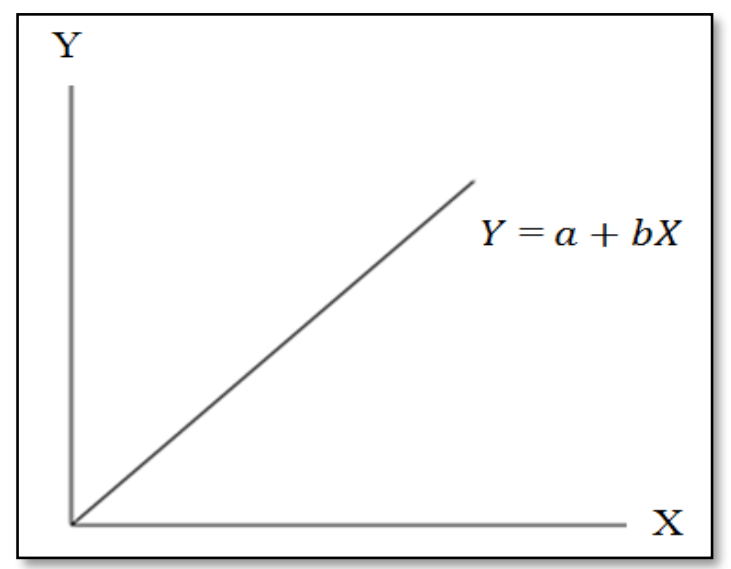

Gambar 1. Ilustrasi Garis Regresi Liniear

\section{METODE PENELITIAN}

\subsection{Lokasi Penelitian}

Penelitian ini dilakukan pada ruas jalan W.R Supratman Kota Bengkulu. Gedung J Universitas Bengkulu yang menjadi titip pusat analisa penelitian dengan tinjauan pola pergerakan agen dari titik kumpul gedung untuk melakukan evakuasi ke pintu keluar Universitas Bengkulu. 


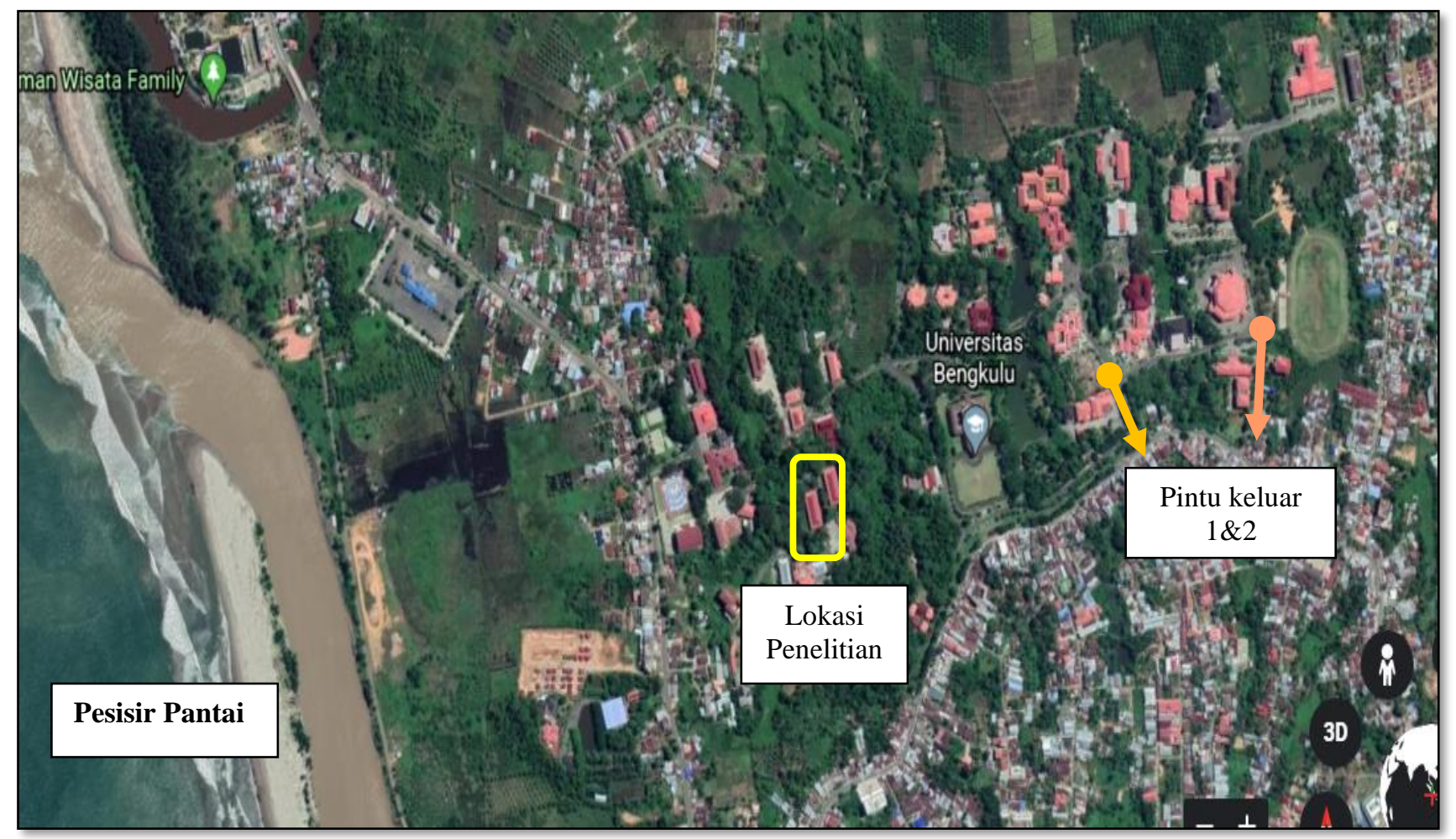

Gambar 2. Lokasi Penelitian (dimodifikasi dari Google Earth, Zona Universitas Bengkulu 2019)

\subsection{Teknik Analisis Data}

Dalam menganalisis kinerja jaringan jalan pada saat melakukan evakuasi, maka dilakukan tahapan sebagai berikut:
a. Data primer (geometri jalan, denah gedung, dan kuesioner)
b. Data sekunder (Peta jaringan jalan dan data responden gedung J Universitas Bengkulu)
c. Pengolahan data jaringan
d. Pengaturan awal analisis
e. Perhitungan kinerja jaringan jalan
f. Pembuatan bahasa pemrograman
g. Simulasi

\section{HASIL DAN PEMBAHASAN}

\subsection{Jumlah Pengungsi Gedung J}

Ketika terjadi evakuasi bencana pengguna Gedung J Universitas Bengkulu terdiri dari 230 orang laki-laki dan 129 orang perempuan dengan rentang usia 18-48 tahun yang meliputi mahasiswa, dosen, dan karyawan.

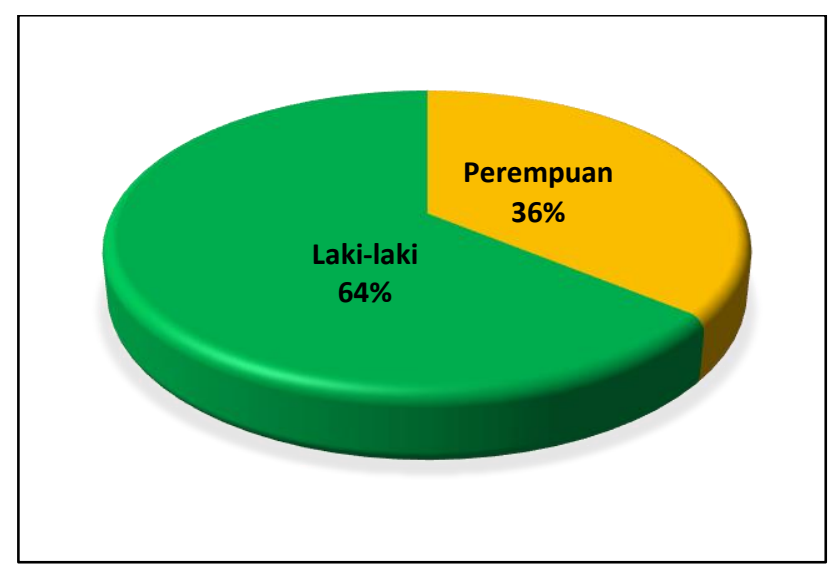

Gambar 3. Persentase Pengguna gedung J 


\subsection{Survei Parkir}

Waktu puncak kendaraan berdasarkan hasil survei lapangan pada tanggal 6 April 2019 terjadi pada pukul 10.00-11.00 WIB. Waktu puncak ini sebagai acuan penulis dalam menentukan waktu terjadinya tsunami.

\subsection{Jaringan Jalan}

Jaringan jalan lokal lingkungan kampus Universitas Bengkulu merupakan data informasi geografis yang diolah lebih lanjut menggunakan aplikasi ArchMap dan AutoCad dan disimpan dalam bentuk format shapefile (.shp). Kemudian pemberian nama pada ruas jaringan jalan dilakukan pada pilihan rute alternatif yang digunakan pada penelitian ini. Ruas jalan diambil antara setiap simpang dengan nama R-1 sampai dengan R-12 dan 3 alternatif rute jalan. Berikut ini rute evakuasi pada saat evakuasi:

a. Alternatif satu melalui beberapa ruas jalan R01(Gedung J-Dekanat Pertanian), R02(Dekanat Pertanian-Rektorat), R05(TIPGB5), R11(GB3-GSG), R12(GSG-Pintu keluar) dengan jarak 1554 meter.

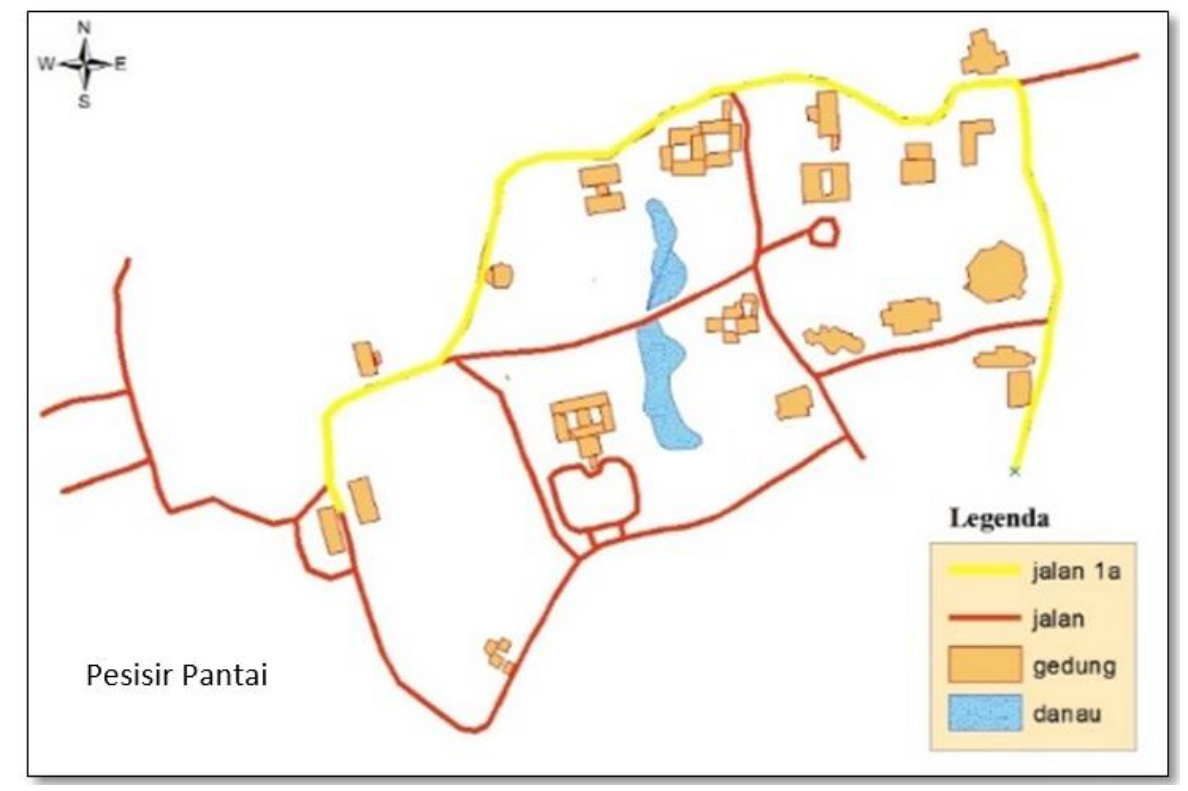

Gambar 4. Rute Alternatif Satu

b. Alternatif dua melalui beberapa ruas jalan R01 (Gedung J Fakultas Pertanian), R02 (Fakultas Pertanian-Rektorat), R06 (Rektorat-GB2), R08 (GB2-LPTIK), R09 (LPTIK-Pintu keluar), R010 (LPTIK-GSG), R012 (F.Teknik-Pintu Keluar) dengan jarak 1291 meter.

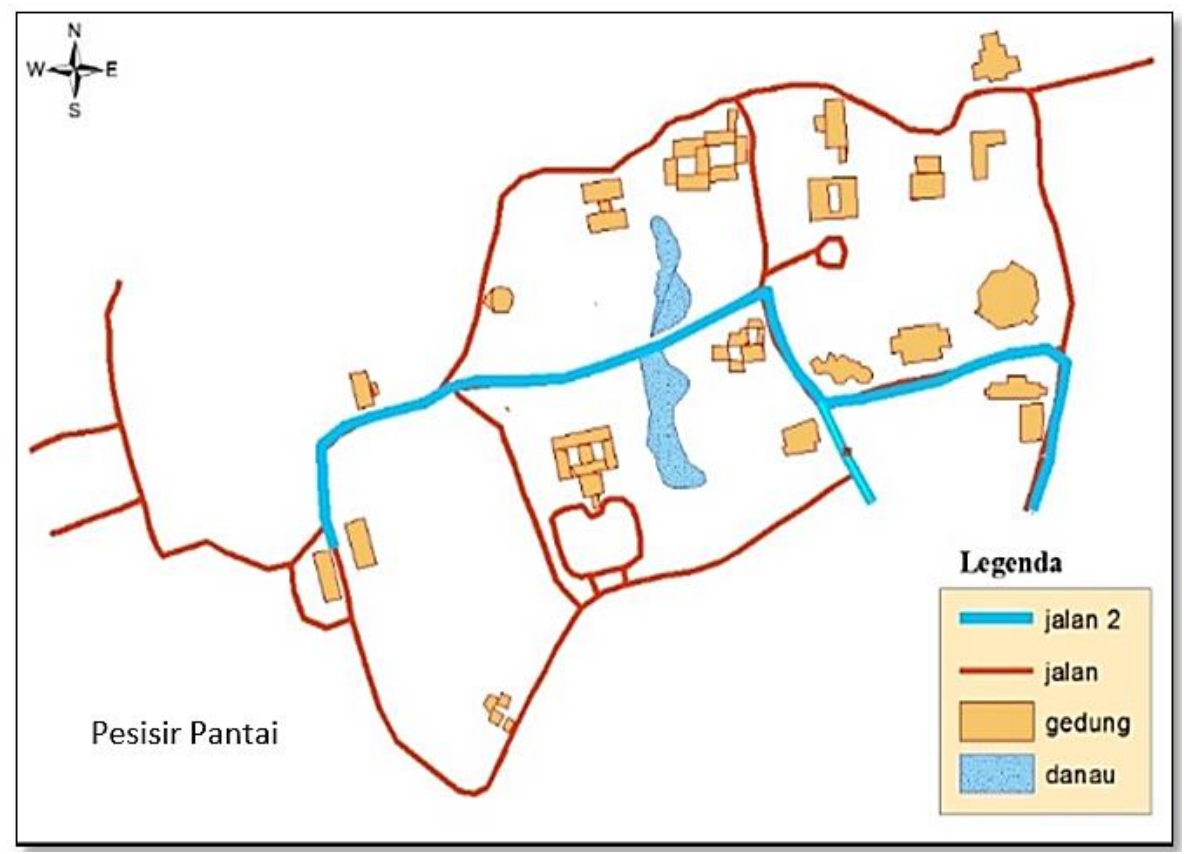

Gambar 5. Rute Alternatif Dua 
c. Alternatif tiga rute evakuasi melalui ruas jalan R01(Gedung J-UPT bahasa), R03(UPT-Rektorat), R07(Rektorat-Fisip), R09(Pintu keluar), R10(LPTIK-GSG), R12(Fakultas Teknik-Pintu keluar) dengan panjang 1373 meter.

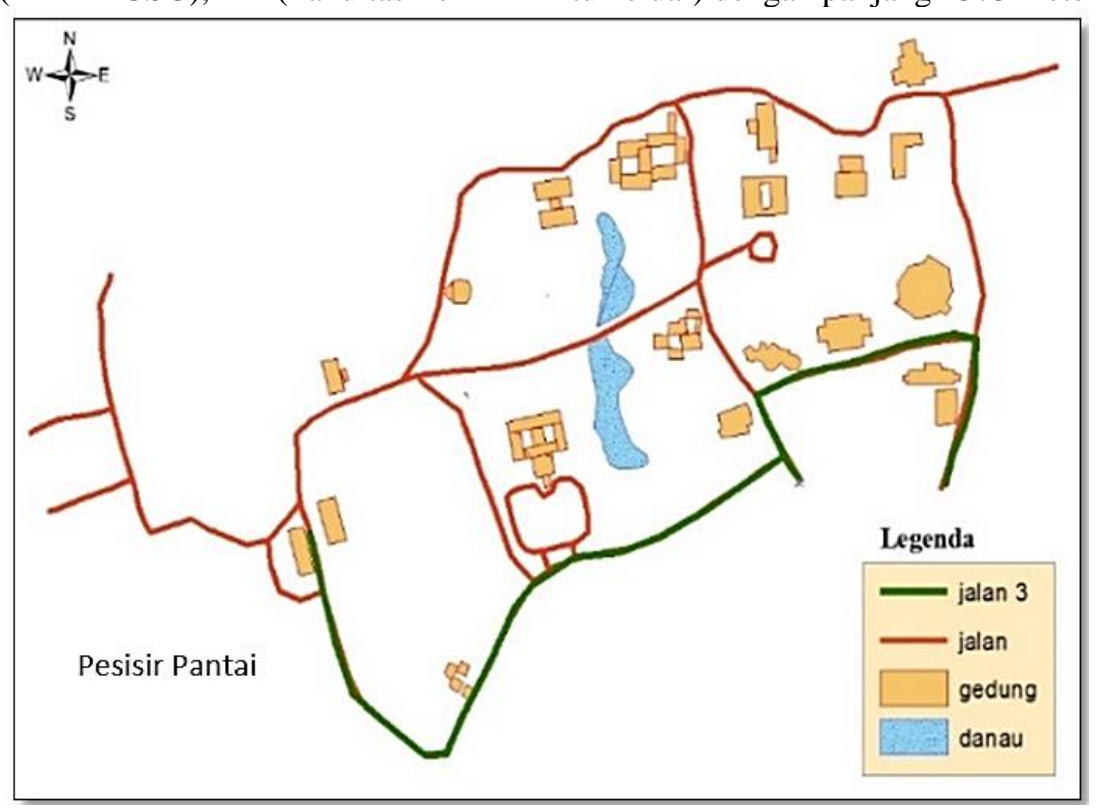

Gambar 6. Rute Alternatif Tiga

\subsection{Hasil Percobaan}

Hasil dari percobaan pengembangan NetLogo pada penelitian ini dapat ditunjukkan pada Lampiran 1. Salah satu sifat dari NetLogo adalah bahwa output permodelan dari agent yang dihasilkan bersifat stokastik, artinya hasil yang diperoleh selalu berubah setiap kali percobaan dilakukan. Percobaan menggunakan behavior space running yang dilakukan berkali-kali. Penentuan jumlah sampel percoban menggunakan tabel Isaac dan Michael dengan faktor kesalahan 5\% diperoleh sebanyak 265 kali percobaan. Kemudian untuk melihat angka regresi maka dilakukan validasi. Validasi ini membandingkan volume pergerakan evakuasi saat kondisi riil dan pada saat permodelan. Angka validasi yang diperoleh sebesar 93,12\%.

\subsection{Analisis Kinerja Model}

Data geometrik dari ruas jalan yang akan ditinjau dibutuhkan dalam menghitung kapasitas ruas jalan. pengolahan data hasil percobaan, mengetahui kapasitas ruas jalan, derajat kejenuhan $\left(D_{J}\right)$, kecepatan, dan waktu tempuh pada ruas jalan yang dilalui oleh agen dapat dilakukan untuk analisis output pada NetLogo. Tabel 1 berikut menunjukkan data geometrik dari ruas jalan tinjauan berdasarkan hasil survei yang telah dilakukan di lapangan.

Tabel 3. Data geometrik ruas jalan

\begin{tabular}{|c|c|c|c|c|}
\hline No & $\begin{array}{l}\text { Kode } \\
\text { Jalan }\end{array}$ & Tipe Jalan & $\begin{array}{l}\text { Lebar Jalan } \\
\text { (m) }\end{array}$ & $\begin{array}{c}\text { Lebar Bahu } \\
\text { (m) }\end{array}$ \\
\hline 1 & R01 & $2 / 2 \mathrm{TT}$ & 4 & 0,5 \\
\hline 2 & R02 & $2 / 2 \mathrm{TT}$ & 5 & 0,5 \\
\hline 3 & R03 & $2 / 2 \mathrm{TT}$ & 4 & 0,5 \\
\hline 4 & R04 & $2 / 2 \mathrm{TT}$ & 5 & 0,5 \\
\hline 5 & R05 & $2 / 2 \mathrm{TT}$ & 4,5 & 0,5 \\
\hline 6 & R06 & $2 / 2 \mathrm{TT}$ & 5 & 0,5 \\
\hline 7 & R07 & $2 / 2 \mathrm{TT}$ & 6 & 0,5 \\
\hline 8 & R08 & $2 / 2 \mathrm{TT}$ & 7 & 0,3 \\
\hline 9 & R09 & $2 / 2 \mathrm{TT}$ & 8 & 0,5 \\
\hline 10 & $\mathrm{R} 10$ & $2 / 2 \mathrm{TT}$ & 6 & 0,5 \\
\hline 11 & R11 & $2 / 2 \mathrm{TT}$ & 4,5 & 0,3 \\
\hline 12 & $\mathrm{R} 12$ & $2 / 2 \mathrm{TT}$ & 4,5 & 0,3 \\
\hline
\end{tabular}


Dalam membandingkan interaksi antara harian dan model pada perjalanan harian dan permodelan pada Gedung $\mathbf{J}$ dapat dilakukan dengan menganalisis Derajat kejenuhan $\left(D_{J}\right)$. Analisis $D_{J}$ diolah menggunakan PKJI 2014. Hasil analisis DJ pada permodelan di ruas jalan tinjauan dari Gedung .

Tabel 4. Derajat Kejenuhan Evakuasi

\begin{tabular}{|c|c|c|c|c|c|c|c|c|c|c|c|}
\hline \multirow{3}{*}{ No } & \multirow{3}{*}{$\begin{array}{c}\text { Kod } \\
\mathrm{e}\end{array}$} & \multirow{2}{*}{$\begin{array}{c}\text { Volume } \\
\text { model }\end{array}$} & \multicolumn{3}{|c|}{ Distribusi Mode (\%) } & \multicolumn{3}{|c|}{ Kapasitas Angkut } & \multirow{2}{*}{$\begin{array}{l}\text { Volume } \\
\text { Model }\end{array}$} & \multirow[b]{2}{*}{$\begin{array}{c}\text { Kapasitas } \\
\text { jalan }\end{array}$} & \multirow{3}{*}{ VCR } \\
\hline & & & MC & $\mathbf{L V}$ & HV & MC & $\mathbf{L V}$ & $\begin{array}{l}\text { Jalan } \\
\text { Kaki }\end{array}$ & & & \\
\hline & & orang & $51 \%$ & $13 \%$ & $0 \%$ & 0.4 & 1 & $\mathbf{0}$ & skr/jam & skr/jam & \\
\hline 1 & R01 & 132 & 67.32 & 17.16 & 0 & 26.93 & 17.16 & 0 & 44.08 & 1118.74 & 0.039 \\
\hline 2 & R02 & 47 & 23.97 & 6.11 & 0 & 9.59 & 6.11 & 0 & 15.69 & 1118.74 & 0.014 \\
\hline 3 & R03 & 79 & 40.29 & 10.27 & 0 & 16.12 & 10.27 & 0 & 26.38 & 1118.74 & 0.023 \\
\hline 4 & R04 & 59 & 30.09 & 7.67 & 0 & 12.04 & 7.67 & 0 & 19.70 & 1118.74 & 0.017 \\
\hline 5 & R05 & 6 & 3.06 & 0.78 & 0 & 1.22 & 0.78 & 0 & 2.00 & 1118.74 & 0.001 \\
\hline 6 & R06 & 52 & 26.52 & 6.76 & 0 & 10.61 & 6.76 & 0 & 17.36 & 1118.74 & 0.015 \\
\hline 7 & R07 & 83 & 42.33 & 10.79 & 0 & 16.93 & 10.79 & 0 & 27.72 & 1118.74 & 0.024 \\
\hline 8 & R08 & 30 & 15.30 & 3.90 & 0 & 6.12 & 3.90 & 0 & 10.02 & 1118.74 & 0.009 \\
\hline 9 & R09 & 186 & 94.86 & 24.18 & 0 & 37.94 & 24.18 & 0 & 62.12 & 1118.74 & 0.055 \\
\hline 10 & R10 & 97 & 49.47 & 12.61 & 0 & 19.79 & 12.61 & 0 & 32.39 & 1118.74 & 0.029 \\
\hline 11 & R11 & 64 & 32.86 & 8.38 & 0 & 13.15 & 8.38 & 0 & 21.52 & 1118.74 & 0.019 \\
\hline 12 & R12 & 137 & 69.87 & 17.81 & 0 & 27.95 & 17.81 & 0 & 45.75 & 1118.74 & 0.030 \\
\hline
\end{tabular}

Tabel 5. Derajat Kejenuhan Harian

\begin{tabular}{|c|c|c|c|c|c|c|c|c|c|c|c|}
\hline \multirow{3}{*}{ No } & \multirow{3}{*}{ Kode } & \multirow{2}{*}{$\begin{array}{c}\text { Volume } \\
\text { model }\end{array}$} & \multicolumn{3}{|c|}{ Distribusi Mode (\%) } & \multicolumn{3}{|c|}{ Kapasitas Angkut } & \multirow[b]{2}{*}{ Volume Model } & \multirow{2}{*}{$\begin{array}{c}\text { Kapasitas } \\
\text { jalan }\end{array}$} & \multirow{3}{*}{ VCR } \\
\hline & & & MC & LV & HV & MC & $\mathbf{L V}$ & $\begin{array}{c}\text { Jalan } \\
\text { Kaki }\end{array}$ & & & \\
\hline & & orang & $48 \%$ & $15 \%$ & $0 \%$ & 0.4 & 1 & $\mathbf{0}$ & skr/jam & skr/jam & \\
\hline 1 & R01 & 121 & 61.71 & 15.73 & 0 & 24.68 & 15.73 & 0 & 40.4140 & 2531.909 & 0.0160 \\
\hline 2 & R02 & 30 & 15.30 & 3.90 & 0 & 6.12 & 3.90 & 0 & 10.0200 & 1312.842 & 0.0076 \\
\hline 3 & R03 & 65 & 33.15 & 8.45 & 0 & 13.26 & 8.45 & 0 & 21.7100 & 1312.842 & 0.0165 \\
\hline 4 & R04 & 49 & 24.99 & 6.37 & 0 & 9.99 & 6.37 & 0 & 16.3660 & 1312.842 & 0.0125 \\
\hline 5 & R05 & 8 & 4.08 & 1.04 & 0 & 1.63 & 1.04 & 0 & 2.6720 & 1312.842 & 0.0020 \\
\hline 6 & R06 & 52 & 26.52 & 6.76 & 0 & 10.61 & 6.76 & 0 & 17.3680 & 1312.842 & 0.0132 \\
\hline 7 & R07 & 65 & 33.15 & 8.45 & 0 & 13.26 & 8.45 & 0 & 21.7100 & 2039.593 & 0.0106 \\
\hline 8 & R08 & 26 & 13.26 & 3.38 & 0 & 5.30 & 3.38 & 0 & 8.6840 & 1440.569 & 0.0060 \\
\hline 9 & R09 & 154 & 78.54 & 20.02 & 0 & 31.42 & 20.02 & 0 & 51.4360 & 1440.569 & 0.0357 \\
\hline 10 & R10 & 86 & 43.86 & 11.18 & 0 & 17.54 & 11.18 & 0 & 28.7240 & 2039.593 & 0.0141 \\
\hline 11 & R11 & 55 & 28.05 & 7.15 & 0 & 11.22 & 7.15 & 0 & 18.3700 & 1312.842 & 0.0140 \\
\hline 12 & R12 & 144 & 73.44 & 18.72 & 0 & 29.38 & 18.72 & 0 & 48.0960 & 1440.569 & 0.0334 \\
\hline
\end{tabular}




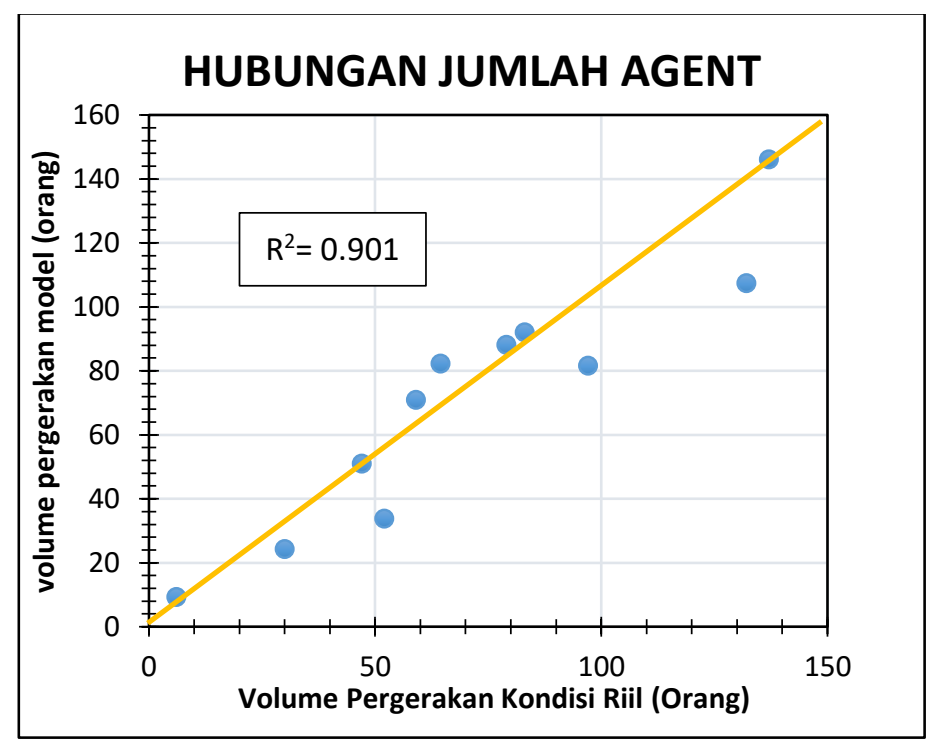

Gambar 7. Grafik Regresi Linear

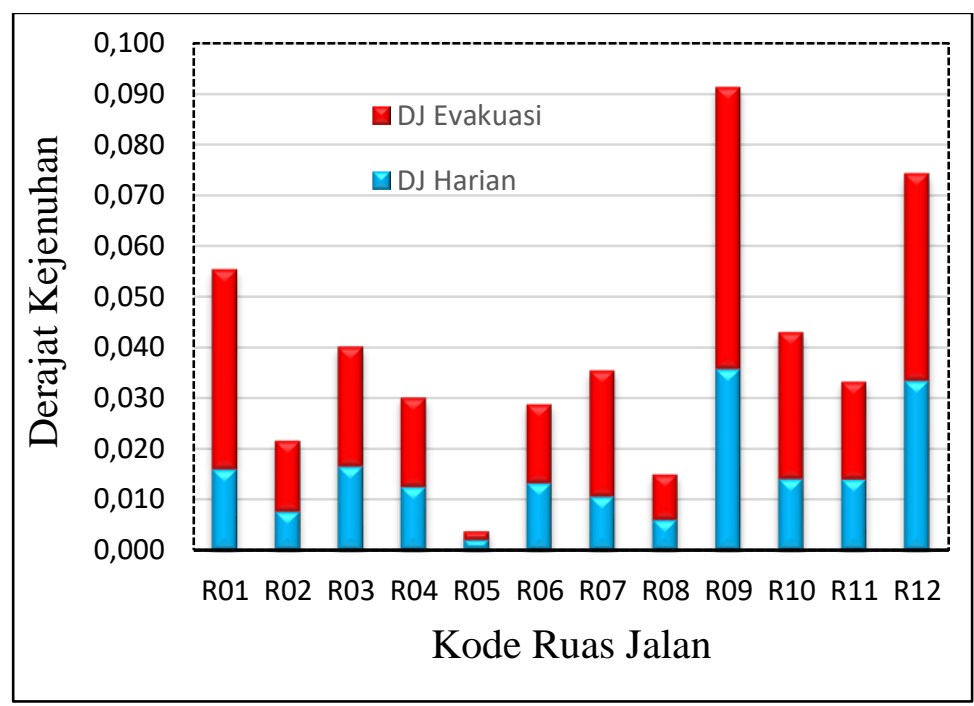

Gambar 8. Hubungan Derajat Kejenuhan harian dan model

Hubungan kecepatan berdasarkan alternatif rute yang dipakai. Persamaan $v=s / t$ dapat digunakan untuk menganalisis kecepatan agen pada ruas jalan, dimana $\mathrm{v}$ adalah kecepatan $(\mathrm{km} / \mathrm{jam})$, s adalah jarak pada ruas jalan $(\mathrm{km})$, dan $\mathrm{t}$ adalah waktu tempuh (jam). Perbandingan kecepatan harian dan model dapat dilihat pada Gambar.

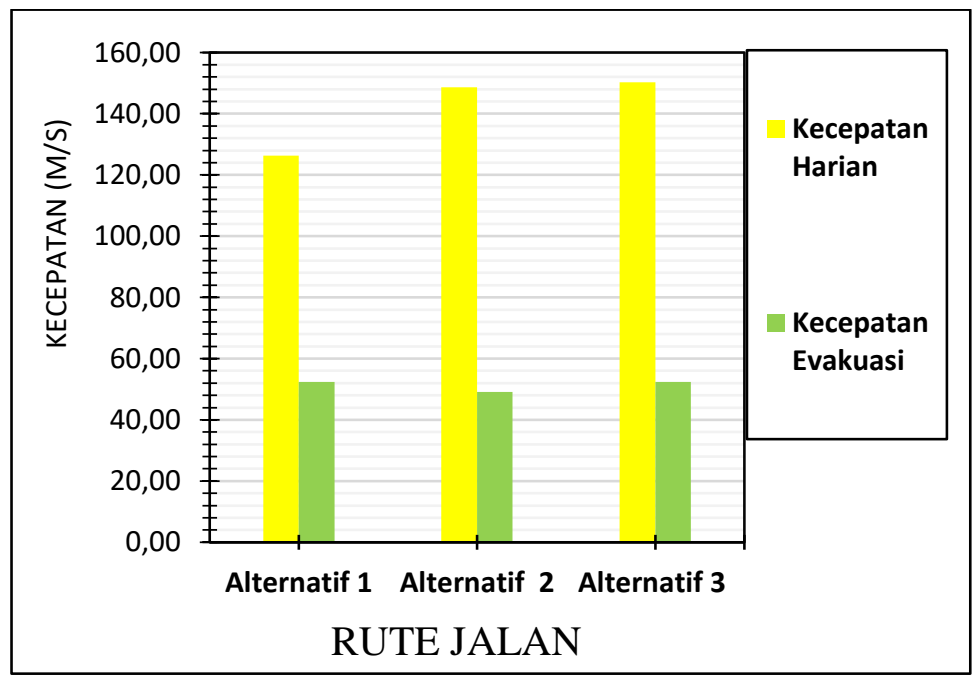

Gambar 9. Hubungan Kecepatan dan Alternatif yang dipilih 


\section{KESIMPULAN DAN SARAN}

Berdasarkan hasil analisis dan pembahasan, maka dapat ditarik kesimpulan sebagai berikut:

1. Jumlah pengguna Gedung J sebanyak 359 orang dengan ruas jalan yang digunakan merupakan jenis jalan lokal yang memiliki kapasitas jalan tertinggi sebesar 1966,27 skr/jam.

2. Berdasarkan tiga jalur alternatif evakuasi, jalur satu dan dua yang paling banyak dipilih. Persentase jalur alternatif evakuasi, alternatif 1 (29,70\%), alternatif 2 (34,94\%), dan alternatif $3(25,33 \%)$.

3. Hasil Validitas analisis menggunakan regresi linear sederhana dengan nilai $93,12 \%$. Nilai derajat kejenuhan (DJ) maksimum 0,0349 pada ruas R01 jalan menuju pintu keluar. Dan derajat kejenuhan minimum 0,0040 pada ruas R08 jalan GB2 menuju LPTIK Universitas Bengkulu. Analisis berbasis agent memiliki kecepatan kendaraan yang mengalami keterlambatan pada semua jaringan jalan dengan waktu tempuh rata 3 sampai 3,5 menit untuk sampai ke pintu keluar Universitas Bengkulu.

Saran yang dapat diberikan sebagai berikut:

1. Perlu adanya penelitian lanjutan terkait waktu tempuh evakuasi dan pemodelan.

2. Perbaikan berkala jaringan jalan Universitas Bengkulu, sehingga tidak menimbulkan kepadatan ketika proses evakuasi berlangsung.

\section{UCAPAN TERIMA KASIH}

Terima kasih penulis ucapkan kepada Pihak yang mengelola Gedung J Universitas Bengkulu yang telah membantu dalam penulisan penelitian di Gedung J Universitas Bengkulu, sehingga penelitian dapat terselesaikan dengan baik.

\section{DAFTAR PUSTAKA}

[1] Natawidjaja, D. H. (2007). Gempa Bumi dan Tsunami di Sumatra dan Upaya Untuk Mengembangkan Lingkungan Hidup. $1-136$.

[2] Departemen Kesehatan RI (2001). Mitigasi Bencana. Jakarta: Depkes RI.

[3] Manini, D.J, Madireddy., Soundar, M., Kumara (2011). Model Berbasis Agent Manajemen Lalu Lintas Evakuasi. Prosiding Konferensi silmulasi Musim Dingin Jain, RR Cr easey, J. Himmelspach, KP White, \& M. fu, eds.

[4] Nurfaida. (2016). Penggunaan SIG Untuk Pemetaan Jalur -Evakuasi Bencana Tsunami Di Desa Tonggolobibi Kecamatan Sojol. E-Journal Geo-Tadulako UNTAD, 1-14.

[6] Hardiansyah. (2018). Identifying Road Network Vulnerability During Disaster Cased study: Road Network Evacuation in Merapi Eruption. Songklanakarin Journal of Science and Technology, 1-24.

[7] Bata, Julius. (2012). Silmulasi Agent Based Modelling (ABM) Menggunakan NetLogo. Seminar Nasional Teknologi Informasi dan Komunikasi 2012 (SENTIKA 2012). ISSN: 2089-9815. Lab Pengembangan Simulasi dan Game Edukasi, PAUD Dunia Beta. Kupang.

[8] Direktorat Jendral Bina Marga. (2014). Pedoman Kapasitas Jalan Indonesia (PKJI). Jakarta: Direktorat Bina Marga. 